\title{
The Interrelated Influence of Organizational Energy and Autopoietic Endowments of Works Council Members
}

\author{
Mari Božič * \\ Faculty of Organizational Studies, Ulica talcev 3, 8000 Novo mesto, Slovenia \\ mari.bozic@gmail.com
}

Annmarie Gorenc Zoran

Faculty of Organizational Studies, Ulica talcev 3, 8000 Novo mesto, Slovenia

a.zoran@fos-unm.si

\begin{abstract}
:
Research Question (RQ): Research shows that organizations need employee energies to function, resulting in the processes of creation, the achievement of goals, and collaboration at all levels. In this research study, we are interested whether there exists an interrelated influence of Organizational Energy (Productive Energy, Comfortable Energy, Resigned Inertia, Corrosive Energy) and Autopoietic Endowments (Self-Awareness, Conscience, Independent Will, Creative Imagination) of employees. We selected Works Council members in Slovenian organizations as the target group for conducting the research study.

Purpose: The purpose of the research was to examine the interrelated influence of organizational energy and autopoietic endowments of employees, assuming that a higher level of autopoietic endowments is reflected in a higher value of quality organizational energy. The purpose of this study was also to verify the research instrument.

Method: We used a questionnaire as a measuring instrument to collect information for the pilot research. The questionnaires were based on two existing questionnaires and scholarly literature in our field of interest.

Results: The research findings confirm the interrelatedness between Autopoietic Endowments and Organizational Energy of Works Council members. However, to check the influence of the independent variable on the dependent one, a larger sample would be needed. The results also revealed that the participants in the study had a higher value of quality- than low-quality energies, which indicates the participants constructive use of personal potentials.

Organization: The existence of interrelated influences of Autopoietic Endowments and Organizational Energy is an important insight for organizations that contributes to the understanding of organizational energy management.

Society: The conducted research represents a contribution to new findings in the field of implementation of workers' participation in organizations in Slovenia.

Originality: There is a dearth amount of research on the topics and the authors did not find research that intertwines organizational energy and the principles of autopoiesis in the context of workers' participation, either in Slovenia or globally.

Limitations / further research: The research was conducted in the form of a pilot study to verify the reliability of the questionnaire. The pilot study could be extended to a larger sample, but due to the separation of participants between the pilot and the main research, we decided to obtain a larger sample in the primary research. However, we tried to overcome the limitation by looking for a sample greater than 25 , which is an acceptable number for conducting a pilot study to test the questionnaire.
\end{abstract}

Keywords: organization, workers' participation, works council, works council members, autopoietic endowments, organizational energy.

* Korespondenčni avtor / Correspondence author 


\section{Introduction}

Constant change in all areas of social life presents organizations with new challenges, which raise the question of how to handle employees to overcome everyday obstacles in the workplace successfully. In this context, Budd, Gollan, and Wilkinson (2010, p. 305) find that much of the literature on employee management highlights the importance of workers' participation, especially in terms of contributing employees' knowledge and skills to improving an organization's operations.

Bulc (2006, p. 19) explains that business systems can be seen as a natural form of coexistence and development that has its dynamics of development, history, present, and future. Changes in business systems follow social and economic logic, and these systems primarily follow the sociological development of a person - at the individual level of liberation, self-awareness, and self-realization. In the light of the perception of an organization as a living organism, whose supporting factor of development is the vital energy of the individual, informal forms of cooperation are coming to light, which is approaching the natural forms of coexistence and development. Involving as many employees as possible in the development and formation of an organization may be achieved by management in a participatory way. In addition to managers at different levels, management can also be assisted by Works Council members, who should be informed individuals and be a role model to their colleagues with their own qualities and values.

Management should understand Works Council members as ambassadors of change, who bring a new way of thinking to their work environments and thus influence employee relations, which are crucial for the realization of the organization's goals. Integrating workers' participation in their daily routine thus involves promoting a positive attitude towards life, understanding their own strengths and limitations, and values such as respect, trust, openness, and diversity. Consequently, Works Council members should have specific characteristics and be able to invoke them to attract as many of their employees as possible into their circle. They will be more effective when they focus their energy on providing sense to work tasks to their colleagues, enthusiasm for goals, and promoting a pleasant atmosphere, all of which are vital for a productive work environment. The well-being of the individual as well as the well-being of the group is essential, namely because the well-being of all co-workers influences individuals to have a positive attitude, regardless of the type of task. Možina (2004, p. 4) explains that the guarantee for a group's success is a pleasant atmosphere that facilitates relaxed activities and satisfaction with work and cooperation, thus achieving a source of motivation for further engaged work.

The personality traits of individuals, and therefore of Works Council members, are important for their proactive functioning because these traits can help build relationships in an organization. If management, in cooperation with employee representatives, is able to provide the support it needs to run the organization; management will accept the Works Council 
members as a partner in decision-making. On the other hand, to build good relationships, it is important to attract co-workers. Works Council members, as facilitators of information between co-workers and management, can increase the level of mutual trust and thus contribute to strengthening relationships. Finding opportunities to act proactively is everyone's job. Each Works Council members should, through the advancement of knowledge and acting on the principles and values in practice, ensure that their mission is to perform qualitatively and effectively in the direction of strengthening interpersonal relations of employees and relations with management. In this context, the research presented in this article measured the organizational energy of Works Council members and their autopoietic endowments and examined the interrelated influence of organizational energy and autopoietic endowments of Works Council members.

The research was conducted in the form of a pilot research to verify the reliability of the questionnaire. The main research will aim to develop a model of the influence of autopoietic endowments of Works Council members on their organizational energy and relations with management.

There is a dearth of research that intertwines organizational energy and principles of autopoiesis in the context of workers' participation, either in Slovenia or globally. For this reason, this research represents a contribution to new findings in the field of implementation of workers' participation in organizations.

The findings of the research will be of practical use to Works Council members in representing the interests of workers in the organization, as enhancing these individuals' autopoietic endowments can contribute to their proactive approach to workers' participation. Similarly, the findings of the research will be useful for all employees who have an important role and a responsibility to nominate and elect as their representatives those employees who have the necessary characteristics to work for the benefit of all employees and concurrently towards the successful operation of the organization.

\section{Theoretical framework}

Vaupotič et al. (2015, p. 9) noted that in contemporary social science literature, the concept of workers' participation emerges in different meanings. Today, in the field of business sciences, it is mostly used as a general designation for all forms of modern employee participation. These include, in particular, employee participation in management or employee comanagement, employee participation in profit or other results, and broader internal ownership of employees.

Franca (2009, pp. 46-47) explains that workers' participation in a broad sense means the participation of workers in the form of specific bodies, such as the workers' council and the workers' trustee, workers' representatives in the organization's governing bodies, and all modes and forms of cooperation, used by workers, regardless of their intensity or degree of 
participation. Workers' participation in the narrow sense refers only to the co-decision of workers.

Brečko (2012) explains that organizations require the energy of their employees for their operations, which results from their processes of creation, the achievement of goals, and cooperation at all levels. This combined energy helps to shape the winning power and mindset of employees. Bukovec (2006) notes that the driver of all progress is closely linked to the human desire for a better, more enjoyable, comfortable, safer, happier, or more prosperous life. Hence, an individual develops specific criteria, approaches, ways, values, personal philosophy, or in other words, a paradigm, whether it is willful or inadvertent, knowing or unknowing. Individuals form their unique view of life and events that take place in one's environment, as well as a unique understanding of events, things, or concepts. In this way, an individual forms his or her own thought pattern or paradigm about success and quality of life. Covey (1998, p. 52; 2004, p. 42) recognizes free choice between response and stimulus, and in this freedom of choice, human self-awareness, imagination, conscience, and independent will are crucial. The author further emphasizes that developing all four of these human traits is essential to be proactive. None should be neglected because the essence lies in the synergy or relationship between them. He defines the free choice of response to stimulus relative to self-awareness, imagination, conscience, and independent will as a proactive model (Covey, 1998, p. 52).

For proactive action of Works Council members, their personal characteristics are therefore necessary, because only with such action can they constructively represent the interests of the employees in the organization. Namely, if management in cooperation with employee representatives will be able to provide the support it needs to run the organization, it will accept the Works Council as a partner in decision-making. Finding opportunities for proactive action is the task of each individual. Through the advancement of knowledge and action based on principles and values in practice, each member of the Works Council should ensure that he or she carries out his or her mission in a quality-oriented and efficient manner towards strengthening interpersonal relations of employees and relations with management.

Lauc (2000) notes that through biology, we are able to understand the forces of causality, and with philosophy, the forces of consequence. Thus, from both disciplines, we obtain a mental framework in which through psychology, technology, economics, and law, we control the laws of development of each organization. It is therefore necessary to make ourselves into strong personalities and learn to set goals autopoietically, based on Covey's (1998) four principles:

(1) Through conscience, we connect the power of intention, the task, and the power of principles.

(2) Through creative imagination, we imagine new possibilities and creative ways to realize them. 
(3) Through self-awareness, we set goals on a realistic basis, taking into account new findings and experiences.

(4) By independent will, we choose the purpose and the means for the realization of the imagined.

Through these principles is how we transform feelings into thoughts, thoughts into words, and words into actions. By learning, we create ourselves, gain skills, and deepen our creative potential. It is also imperative to be aware of one's emotions and motives. Emotions are happiness in their ideal, and motive is freedom. Everything cognitive is in between, which we need to be happy and satisfied. It is up to each individual to determine, through mastering the theory of motivation, knowledge, and the interaction of the autopoietic elements how one can work better and more efficiently, no matter what job one is doing. (pp. 9-18)

Workers' participation has been the subject of much debate, but in almost all cases, it has been analyzed in terms of the implementation of recognized labor rights by legal acts and the impact of workers' participation on organizational performance. In our research, we focused on Works Council members as individuals. Hence, we did not seek individual's talents, knowledge, and skills, but focused on the autopoietic endowments that we expose as an element or building block to create organizational energy of Works Council members. This is what is needed to achieve workers' participation, just as organizations need the energy generated by employees in their processes of creating and achieving goals and interacting at all levels of an organization's operations. Covey (1998, pp. 47-52) derives the fundamental principle of human nature from the fact that an individual is free to choose one's response to stimulus. The author recognizes free choice between response and encouragement, and in this freedom of choice, the key human endowments are self-awareness, imagination, conscience, and independent will. The development of all four personality endowments is key to a person's proactivity or ability to act on principles and values. Brečko (2012, pp. 3-7) explains that organizational energy is a force released by an organization in achieving its goals, and its power shows how much and what kind of emotional, mental, and behavioral potential people have released in their work and achievement of organizational goals.

Our basic thesis is that the organizational energy of an individual is influenced by his or her autopoietic endowments or more specifically, that there is a mutual influence between these two variables, which we wanted to explore further.

In the pilot study, we, therefore, measured the autopoietic endowments and organizational energy of the Works Council members and, based on the results, examined the interrelated influence of the variables.

Our overarching research question is: What is the interaction between autopoietic endowments and organizational energy of Works Council members? 
- Hypothesis 1: There is a statistically significant correlation between autopoietic endowments and organizational energy of Works Council members.

Brečko (2012, p. 3) notes that companies need energy of their employees for their operation, which results from their processes of creation, the achievement of goals, and mutual cooperation at all levels. Autopoietic endowments have been classified into four categories by Covey, Merrill, and Merrill (1997, pp. 56-58): self-awareness, conscience, independent will, and creative imagination. The authors further note that these qualities provide an individual with the most considerable freedom and power to decide, respond, or to change.

Based on these arguments, we hypothesized that there is a statistically significant correlation between autopoietic endowments and organizational energy of Works Council members.

- Hypothesis 2: Self-awareness of Works Council members has a statistically significant effect on their productive energy.

Leary (2000, pp. 209-210) defines self-awareness as a personality trait that refers to directing attention to oneself and thinking about one's motives, emotions, thoughts, and desires. Silvia and O'Brian (2004, p. 475) emphasize the importance of self-awareness in connection with creative achievements, as they would be more challenging to create it without the creator's self-criticism and self-assessment. Authors Silvia and O'Brian (2004, p. 481) and Leary (2004, p. 5) explain that self-awareness is important for the planning and execution of an individual's actions and also for human self-regulation in general.

Brečko (2012, pp. 3-5) explains that five factors have the most significant impact on productive energy: (1) quality management, (2) strategic orientation, (3) confidence in success, (4) commitment, and (5) cooperation between management and employees. Works Council members can significantly influence these factors through proactive action, as they participate in decision-making in accordance with the law. According to their function, members also have the possibility of informing management about the situation of working life in the organization and make suggestions for improvement.

From the above, we hypothesize that self-awareness of Works Council members has a statistically significant effect on their productive energy.

- Hypothesis 3: Independent will of Works Council members has a statistically significant effect on their productive energy.

Ilievski (2017, p. 6) describes Bandur's cognitive-social science concept of independent will, which defines freedom proactively, as an attempt to exert personal influence in relation to set goals and desired results. The author undstands freedom as a relationship between various influences on our ability to act autonomously in an interactive world. Covey, Merrill, and Merrill (1997, pp. 57-58) define independent will as the ability to act that empowers one to 
transcend his or her patterns, swim upstream, rewrite one's guidelines, act on principles instead of response based on emotions and circumstances.

As such, we hypothesized that independent will of Works Council members has a statistically significant effect on their productive energy.

\section{Method}

The validated OEQ16 questionnaire (Brečko, 2017) was used to measure organizational energy, and the questionnaire (Covey, Merrill, \& Merrill, 1997, pp. 59-60; Covey, 1998, pp. 60-61) was used to measure autopoietic endowments. Both instruments were translated from English into Slovenian and, once again, 48 hours later translated into the Slovenian language. This step was integrated to compare for any inconsistencies and discuss among the translators any issues that remain open. The questionnaire was translated by two evaluators, where one is a native speaker of English and an expert in the content area and the other evaluator also an expert in the field with advanced English language proficiency. Table 1 shows the calculation of translation compliance or reliability between translations (Miles \& Huberman, 1994, p. 64).

Table 1. Reliability among Translations

\begin{tabular}{lccc}
\hline & $\begin{array}{c}\text { Number of } \\
\text { Agreements }\end{array}$ & $\begin{array}{c}\text { Number of } \\
\text { Disagreements }\end{array}$ & Reliability \\
\hline Evaluator 1 & 68 & 4 & 0.94 \\
Evaluator 2 & 64 & 2 & 0.97 \\
\hline
\end{tabular}

Therefore, we used a structured questionnaire with which we measured the following key concepts using defined sets of indicators:

- Organizational energy: the variable is divided into four dimensions, each dimension is measured by four indicators from which the total variable was calculated based on the mean of the indicators.

(1) Resigned Inertia, (2) Corrosive Energy,

(3) Productive Energy, and (4) Comfortable Energy

There are a total of four statements on a five-point Likert-type ordinal scale: 1 - very rarely; 2 - rarely; 3 - occasionally; 4 - often; 5 - very often. The total variable has a value between 1 and 5, and a higher score means a higher presence of measured energy in organizational energy.

- Autopoietic endowments: the variable is divided into four dimensions, each dimension is measured by four indicators from which the total variable was calculated based on the mean of the indicators. 
(1) Self-awareness, (2) Conscience,

(3) Independent Will, and (4) Creative Imagination

There are a total of four statements on a five-point Likert-type ordinal scale: 0 - never; 1 - very rarely; 2 - sometimes; 3 - often; 4 - always. The total variable has a value between 1 and 5, and a higher score means a higher presence of measured energy in organizational energy.

The sample of the pilot study included 26 Works Council members $(f=16$ women; $10=$ men), of which 5 were up to 29 years old, 5 participants between 30 and 39, 11 between 40 and 49 , and 5 between the ages of 50 and 59 . We can assume that the sample is quite diverse in terms of age. The same applies to the length of service, of which 10 participants states they have up to 10 years of service in the organization, 10 between 11 and 20 years, and 4 between 21 and 30 years, and 2 over 31 years of service in the organization. The sample included only participants with 5 or higher level of education using the Slovenian Qualifications Framework (SQF, n.d.).

Data from the research results were transferred from 1KA OneClick Survey program and statistically processed. The results were analyzed using the statistical program IBM SPSS 23.0. Tables and graphs were prepared using Microsoft Word and Excel version Office 365.

The results of the pilot study are presented using descriptive statistics. Because we are dealing with a small sample $(n<30)$, only non-parametric tests (Kruskal-Wallis test, Spearman rank correlation coefficient) were used in bivariate analysis. The calculation of the Spearman rank correlation coefficient allowed us to analyze the association between pairs of variables. The strength of correlation or correlation between the variables is inferred from the following scale: 0 - no correlation, $0.1-0.3$ weak correlation, 0.3 - 0.6 moderate correlation, 0.6 - 1 strong correlation).

All sets of indicators were tested and in most cases sufficient reliability (or more specifically, internal consistency) of the questionnaire was achieved (Cronbach $\alpha>0.7$ ). Before calculating the total variables, we excluded specific indicators, which poorly influenced the reliability of the questionnaire. The total variable appearing in the analysis were compiled by calculating mean scores from individual indicators.

\section{Results}

Table 2 shows descriptive statistics for the sets of statements used to measure organizational energy and reliability data. Comparatively, we find that the mean score on a 5-point rating scale are lowest in Resigned Inertia and the Corrosive Energy, where the ratings range around 2. These two energies are therefore less present in the working environments of the participants. However, Productive Energy and Comfortable Energy are more present, where 
the participants have, on average, much higher self-assessed claims, and on average, these revolve around 4.

Table 2. Organizational Energy by Dimensions

\begin{tabular}{|c|c|c|c|c|c|c|}
\hline & & $\mathrm{N}$ & Mean & Median & SD & $\begin{array}{c}\text { Cronbach's } \\
\text { Alpha }\end{array}$ \\
\hline \multirow{4}{*}{$\begin{array}{l}\text { Resigned } \\
\text { Inertia }\end{array}$} & $\begin{array}{l}\text { I feel discouraged at my job (I } \\
\text { feel fear). }\end{array}$ & 26 & 1.73 & 2.00 & 0.83 & \multirow{4}{*}{.893} \\
\hline & $\begin{array}{l}\text { I have a feeling that my } \\
\text { department has no future. }\end{array}$ & 26 & 1.77 & 1.00 & 1.14 & \\
\hline & $\begin{array}{l}\text { I feel that in my department } \\
\text { nothing can be changed. }\end{array}$ & 26 & 2.04 & 2.00 & 1.18 & \\
\hline & I feel exhausted. & 26 & 2.50 & 3.00 & 1.14 & \\
\hline \multirow{4}{*}{$\begin{array}{l}\text { Corrosive } \\
\text { Energy }\end{array}$} & $\begin{array}{l}\text { I get lost in the excessive } \\
\text { number of work activities. }\end{array}$ & 26 & 2.77 & 3.00 & 1.18 & \multirow{4}{*}{.785} \\
\hline & $\begin{array}{l}\text { I often guess about the } \\
\text { objectives and guidelines in } \\
\text { my department. }\end{array}$ & 26 & 2.04 & 2.00 & 1.00 & \\
\hline & $\begin{array}{l}\text { In my department, there are a } \\
\text { lot of rumours. }\end{array}$ & 26 & 2.54 & 3.00 & 0.99 & \\
\hline & $\begin{array}{l}\text { In my department, there are } \\
\text { unsolved conflicts. }\end{array}$ & 26 & 2.12 & 2.00 & 1.24 & \\
\hline \multirow{4}{*}{$\begin{array}{l}\text { Productive } \\
\text { Energy }\end{array}$} & $\begin{array}{l}\text { I am proud of my work (of } \\
\text { what I do). }\end{array}$ & 26 & 4.27 & 4.00 & 0.83 & \multirow{4}{*}{.792} \\
\hline & $\begin{array}{l}\text { I am very loyal to the } \\
\text { organization. }\end{array}$ & 26 & 3.96 & 4.00 & 1.11 & \\
\hline & $\begin{array}{l}\text { I regularly get feedback on } \\
\text { my work performance. }\end{array}$ & 26 & 3.73 & 4.00 & 1.00 & \\
\hline & $\begin{array}{l}\text { We solve problems in teams } \\
\text { and work groups. }\end{array}$ & 26 & 3.77 & 4.00 & 0.91 & \\
\hline \multirow{4}{*}{$\begin{array}{l}\text { Comfortable } \\
\text { Energy }\end{array}$} & I feel relaxed at work. & 26 & 3.85 & 4.00 & 1.05 & \multirow{4}{*}{.693} \\
\hline & $\begin{array}{l}\text { I am satisfied with the } \\
\text { situation in my department. }\end{array}$ & 26 & 3.89 & 4.00 & 0.99 & \\
\hline & $\begin{array}{l}\text { At work and in my } \\
\text { organizational role I work } \\
\text { according to established } \\
\text { patterns. }\end{array}$ & 26 & 3.58 & 4.00 & 0.86 & \\
\hline & $\begin{array}{l}\text { Relations between colleagues } \\
\text { within my department are } \\
\text { calm. }\end{array}$ & 26 & 3.65 & 4.00 & 0.98 & \\
\hline
\end{tabular}

The reliability of the measurement was analyzed by using Cronbach alpha. Values $>0.70$ indicate adequate measurement reliability, between 0.60 and 0.70 satisfactory measurement reliability, and below 0.60 poor measurement reliability (Nunnally, 1978, p. 713). Although our obtained coefficients show at least sufficient measurement reliability, we decided to analyze further whether the reliability could be improved by eliminating potential "dysfunctional items within in a scale" (Cho \& Kim, 2014, p. 217), but only deleting when taking into account logical and theoretical basis. 
Additional analysis for Resigned Inertia (see Table 3) does not indicate that reliability could be increased by eliminating a single indicator, so the total variable was calculated by considering all four indicators.

Table 3. Resigned Inertia: Analysis of Reliability of Individual Statements

\begin{tabular}{lc}
\hline & Cronbach's Alpha if Item Deleted \\
\hline I feel discouraged at my job (I feel fear). & .879 \\
I have a feeling that my department has no future. & .863 \\
I feel that in my department nothing can be changed. & .815 \\
I feel exhausted. & .885 \\
\hline
\end{tabular}

Additional analysis provided by Cronbach's alpha reliability coefficient for Corrosive Energy (see Table 4) shows that reliability could be further increased by eliminating the first indicator. Reliability for the complete set increases when considering three of the four indicators.

Table 4. Corrosive Energy: Analysis of Reliability of Individual Statements

\begin{tabular}{lc}
\hline & Cronbach's Alpha if Item Deleted \\
\hline I get lost in the excessive number of work activities. & .824 \\
I often guess about the objectives and guidelines in my & .696 \\
department. & .681 \\
In my department there are a lot of rumours. & .721 \\
In my department there are unsolved conflicts. & \\
\hline
\end{tabular}

Additional analysis provided by Cronbach's alpha reliability coefficient for Productive Energy (see Table 5) does not indicate that reliability could be further increased by eliminating a single indicator. Reliability for the complete set considers all four indicators.

Table 5. Productive Energy: Analysis of Reliability of Individual Statements

\begin{tabular}{lc}
\hline & Cronbach's Alpha if Item Deleted \\
\hline I am proud of my work (of what I do). & .681 \\
I am very loyal to the organization. & .789 \\
I regularly get feedback on my work performance. & .719 \\
We solve problems in teams and work groups. & .773 \\
\hline
\end{tabular}

Additional analysis provided by Cronbach's alpha reliability coefficient for Comfortable Energy (see Table 6) shows that reliability could be significantly increased by eliminating the third indicator. Reliability for the complete set increases when considering three of the four indicators. 
Table 6. Comfortable Energy: Analysis of Reliability of Individual Statements

\begin{tabular}{lc}
\hline & Cronbach's Alpha if Item Deleted \\
\hline I feel relaxed at work. & .523 \\
I am satisfied with the situation in my department. & .311 \\
$\begin{array}{l}\text { At work and in my organizational role I work according to } \\
\text { established patterns. }\end{array}$ & .798 \\
$\begin{array}{l}\text { Relations between colleagues within my department are } \\
\text { calm. }\end{array}$ & .480 \\
\hline
\end{tabular}

Following is a summary and analysis of sets of statements used to measure autopoietic endowments. Table 7 shows descriptive statistics for all four sets of statements, as well as information on the reliability of the predicted sets of statements.

The results show that all average scores are between 3.0 and 4.5, which are quite high on a 5point scale. For all four sets of statements, the individual statements are above a mean value of 4. The most prominent is the statement 'Am I able to make and keep promises to myself and others?', which has a score of 4.5. On the other hand, each set also has statements with a slightly lower mean value, which is closer to the mean value of 3 . The lowest rated was the statement 'Do I sometimes feel an inner prompting that I should or shouldn't do something I am about to do?' with a mean value of 3.04. The highest mean value was self-assessed with Independent Will and Self-Awareness, slightly lower in Creative Imagination and the lowest in Conscience.

Table 7. Autopoeitic Endownment by Dimensions

\begin{tabular}{|c|c|c|c|c|c|c|}
\hline & & $\mathrm{N}$ & Mean & Median & SD & $\begin{array}{c}\text { Cronbach's } \\
\text { Alpha }\end{array}$ \\
\hline \multirow{4}{*}{ Self-Awareness } & $\begin{array}{l}\text { Am I able to stand apart from my } \\
\text { thoughts or feelings and examine and } \\
\text { change them? }\end{array}$ & 26 & 3.77 & 4.00 & 0.76 & \multirow{4}{*}{.763} \\
\hline & $\begin{array}{l}\text { Am I aware of my fundamental } \\
\text { paradigms and the impact they have on } \\
\text { my attitudes and behaviors and the } \\
\text { results I am getting in my life? }\end{array}$ & 26 & 4.04 & 4.00 & 0.72 & \\
\hline & $\begin{array}{l}\text { Am I aware of a difference between my } \\
\text { biological, genealogical, psychological, } \\
\text { and sociological scripting - and my } \\
\text { own deep inner thoughts? }\end{array}$ & 26 & 3.65 & 4.00 & 0.80 & \\
\hline & $\begin{array}{l}\text { When the response of other people to } \\
\text { me - or something I do - challenges the } \\
\text { way I see myself, am I able to evaluate } \\
\text { that feedback against deep personal self } \\
\text { thought and learn from it? }\end{array}$ & 26 & 4.04 & 4.00 & 0.60 & \\
\hline \multirow{2}{*}{ Conscience } & $\begin{array}{l}\text { Do I sometimes feel an inner prompting } \\
\text { that I should or shouldn't do something }\end{array}$ & 26 & 3.04 & 3.00 & 0.96 & \multirow{2}{*}{.727} \\
\hline & $\begin{array}{l}\text { Do I sense the difference between } \\
\text { "social conscience" - what society has } \\
\text { conditioned me to value and my own }\end{array}$ & 26 & 3.42 & 4.00 & 1.06 & \\
\hline
\end{tabular}




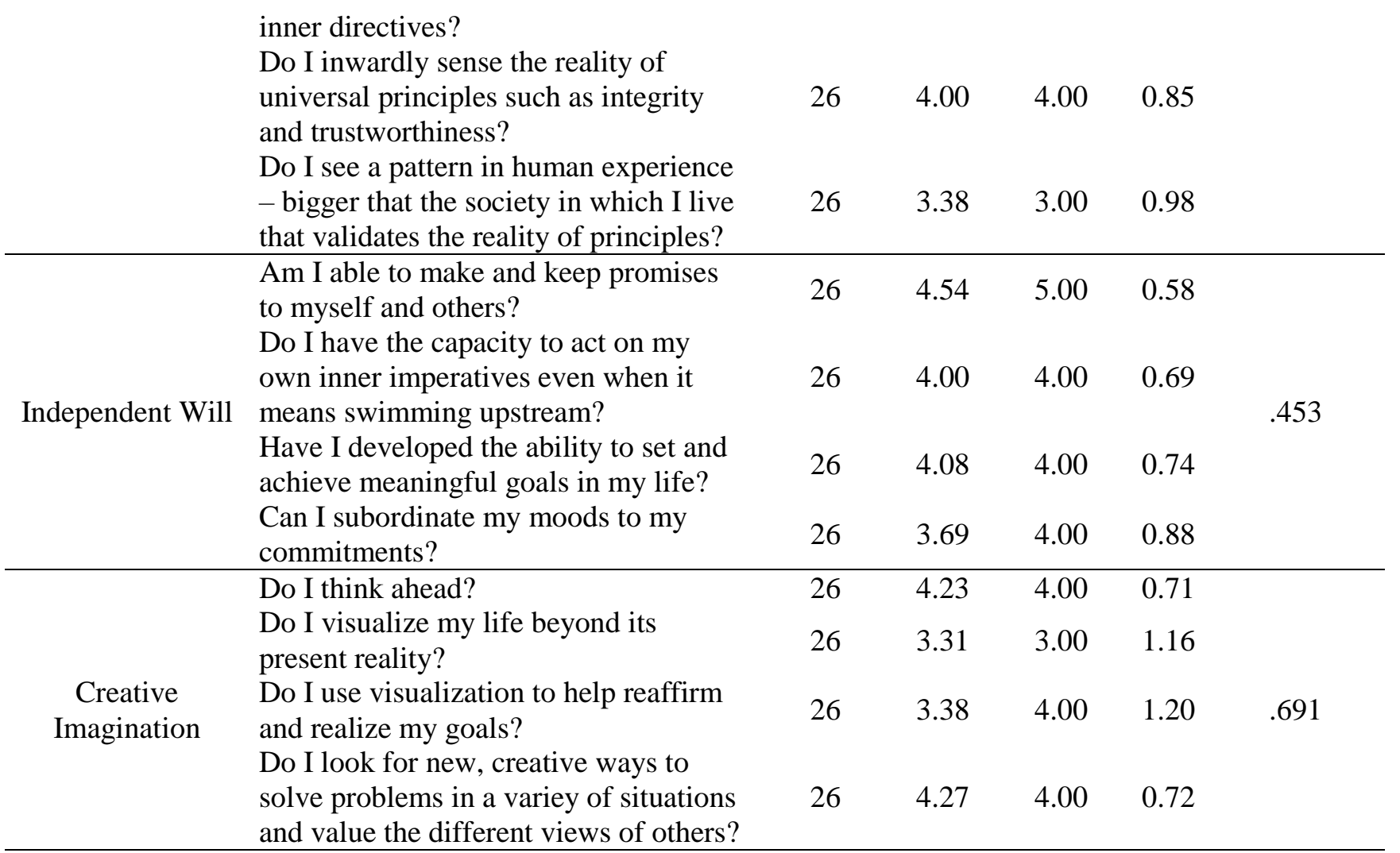

Similarly, as with Organizational Energy (see Table 2), the reliability of the measurement was analyzed using Cronbach alpha, using the same measurement reliability scale (Nunnally, 1978, p. 713) and keeping in mind considerations regarding eliminating certain items (Cho \& Kim, 2014, p. 217). Because the obtained coefficients did not show high reliability of measurement in all instances and because we did not use a standardized questionnaire to measure autopoietic endowments, but one that is in use, we then considered eliminating certain items to see whether values would change.

Additional analysis provided by Cronbach's alpha reliability coefficient for Self-Awareness (see Table 8) does not indicate that reliability could be further increased by eliminating a single indicator. Reliability for the complete set considers all four indicators.

Table 8. Self-Awareness: Analysis of Reliability of Individual Statements

Cronbach's Alpha

if Item Deleted

Am I able to stand apart from my thoughts or feelings and examine and change them? .801

Am I aware of my fundamental paradigms and the impact they have on my attitudes and behaviors and the results I am getting in my life?

Am I aware of a difference between my biological, genealogical, psychological, and sociological scripting - and my own deep inner thoughts?

When the response of other people to me - or something I do - challenges the way I see myself, am I able to evaluate that feedback against deep personal self thought and learn from it? 
Additional analysis provided by Cronbach's alpha reliability coefficient for Conscience (see Table 9) shows that reliability could be significantly increased by eliminating the first indicator. Reliability for the complete set increases when considering three of the four indicators.

Table 9. Conscience: Analysis of Reliability of Individual Statements

\begin{tabular}{lc}
\hline & $\begin{array}{c}\text { Cronbach's Alpha } \\
\text { if Item Deleted }\end{array}$ \\
\hline $\begin{array}{l}\text { Do I sometimes feel an inner prompting that I should or shouldn't do something I am } \\
\text { about to do? }\end{array}$ & .822 \\
$\begin{array}{l}\text { Do I sense the difference between "social conscience" - what society has conditioned } \\
\text { me to value and my own inner directives? }\end{array}$ & .564 \\
$\begin{array}{l}\text { Do I inwardly sense the reality of universal principles such as integrity and } \\
\text { trustworthiness? }\end{array}$ & .536 \\
$\begin{array}{l}\text { Do I see a pattern in human experience - bigger that the society in which I live that } \\
\text { validates the reality of principles? }\end{array}$ & .678 \\
\hline
\end{tabular}

Additional analysis provided by Cronbach's alpha reliability coefficient for Independent Will (see Table 10), which as a whole is not highly reliable, shows that reliability could be significantly increased by eliminating the fourth indicator. Reliability for the complete set increases when considering three of the four indicators.

Table 10. Independent Will: Analysis of Reliability of Individual Statements

Cronbach's Alpha

if Item Deleted

Am I able to make and keep promises to myself and others? .298

Do I have the capacity to act on my own inner imperatives even when it means swimming upstream?

Have I developed the ability to set and achieve meaningful goals in my life?

Can I subordinate my moods to my commitments?

Additional analysis provided by Cronbach's alpha reliability coefficient for Creative Imagination (see Table 11) shows that reliability could be significantly increased by eliminating the first indicator. Reliability for the complete set increases when considering three of the four indicators.

Table 11. Creative Imagination: Analysis of Reliability of Individual Statements

Cronbach's Alpha

if Item Deleted

Do I think ahead?

Do I visualize my life beyond its present reality?

Do I use visualization to help reaffirm and realize my goals?

Do I look for new, creative ways to solve problems in a variey of situations and value the different views of others? 
Table 12 below shows the interrelatedness between Organizational Energy and Autopoietic Endowments of Works Council members.

Table 12. Correlation between Organizational Energy and Autopoietic Endowments

\begin{tabular}{llcccc}
\hline & & Self-Awareness & Conscience & Independent Will & $\begin{array}{c}\text { Creative } \\
\text { Imagination }\end{array}$ \\
\hline Resigned & Spearman's rho & $-.765^{* *}$ & -.296 & $-.570^{* *}$ & -.129 \\
Inertia & $\mathrm{p}$ value & .000 & .142 & .002 & .529 \\
\hline Corrosive & Spearman's rho & $-.751^{* *}$ & -.350 & $-.531^{* *}$ & -.311 \\
Energy & $\mathrm{p}$ value & .000 & .079 & .005 & .122 \\
\hline Productive & Spearman's rho & $.634^{* *}$ & .215 & $.506^{* *}$ & .373 \\
Energy & $\mathrm{p}$ value & .001 & .291 & .008 & .060 \\
\hline Comfortable & Spearman's rho & $.765^{* *}$ & .162 & $.530^{* *}$ & .255 \\
Energy & $\mathrm{p}$ value & .000 & .428 & .005 & .209 \\
\hline $\begin{array}{l}\text { Note. } \mathrm{n}=26 ; * \text { The correlation is statistically significant in value } \mathrm{p}<.05 ; * * \text { The correlation is statistically } \\
\text { significant in value } \mathrm{p}<.01 .\end{array}$ & & & &
\end{tabular}

\section{Discussion}

Following is a discussion of the hypotheses in relation to the results. Our first hypothesis was the following:

H1: There is a statistically significant correlation between autopoietic endowments and organizational energy of Works Council members

In our research, we detected a certain degree of interaction between Autopoietic Endowments and Organizational Energy. Statistically significant correlations with Organizational Energy were detected in two dimensions of Autopoietic Endowments. Namely, Self-Awareness is strongly negatively correlated with Resigned Inertia (rho $=-0.765 ; \mathrm{p}<0.001$ ) and with Corrosive Energy (rho $=-0.751 ; \mathrm{p}<0.001$ ). In terms of interpretation this could signify that these energies are more present in participants with lower self-awareness. On the other hand, we detected strong positive correlations between Self-Awareness and Productive Energy (rho $=0.634 ; \mathrm{p}=0.001$ ) and Self-Awareness and Comfortable Energy (rho = 0.765; $\mathrm{p}<0.01)$. The finding in this case being just the opposite, which is that these energies are more perceived in participants with higher self-awareness.

Another Autopoietic Endowment in which we detected statistically significant correlations is Independent Will. Namely, Independent Will has a moderate negative correlation with Resigned Inertia (rho $=-0.570 ; \mathrm{p}=0.002$ ) and with Corrosive Energy (rho $=-0.531 ; \mathrm{p}=$ 0.005). In terms of interpretation this could signify that these energies are more present in participants with lower expressed independent will. On the other hand, we detected strong positive correlations between Independent Will and Productive Energy (rho $=0.506 ; \mathrm{p}=$ 0.008 ) and Independent Will and Comfortable Energy (rho $=0.530 ; p=0.005)$. The finding in 
this case being just the opposite, which is these energies are more perceived in participants with higher expressed independent will.

There is a statistically significant connection between Autopoietic Endowments and Organizational Energy of Works Council members, thus confirming hypothesis 1 .

H2: Self-awareness of Works Council members has a statistically significant effect on their productive energy.

The correlation between Self-Awareness and Productive Energy is strong with respect to the value of the correlation coefficient and statistically significant with respect to the value of significance (rho $=0.634 ; \mathrm{p}=0.001)$.

The sample of the pilot study was too small to perform a regression analysis to verify the influence of the independent variable on the dependent, so hypothesis 2 cannot be confirmed.

H3: Independent will of Works Council members has a statistically significant effect on their productive energy.

The correlation between Independent Will and Productive Energy is moderate in relation to the value of the correlation coefficient and statistically significant in relation to the value of significance ( $r h o=0.506 ; p=0.008$ ). The sample of the pilot study is too small to perform a regression analysis to verify the influence of the independent variable on the dependent, so hypothesis 3 cannot be confirmed at this time.

The presented results of our research confirm our thesis on the interrelated influence of Autopoietic Endowments and Organizational Energy of Works Council members. However, to be able to verify the influence of the independent variable on the dependent and to accept or fail to accept hypotheses 2 and 3, a larger sample would be needed.

\section{Conclusion}

The purpose of the research was to examine the organizational energy of Works Council members and their autopoietic endowments and to determine whether there is an interaction between these two variables.

The results of the pilot study of organizational energy shows that the mean values on a 5-point rating scale are lowest for Resigned Inertia and Corrosive Energy, where the values were around 2. These two energies, treated as low-quality energies, are less present in the working environments of the participants in our study. More evident are Comfortable Energy and most prominent Productive Energy, where participants rated statements much higher. These two types of energy are considered quality energies. The results thus show that the Works Council member participants in our study, have a higher value of quality- than low-quality energies, which indicates their constructive use of personal potentials. 
Mean scores of autopoietic endowments (Self-Awareness, Creative Imagination, Conscience, Independent Will) are between 3.0 and 4.5, which is quite high relative to the 5-point scale. Covey (1998, p. 52) explains that all four of these human endowments are essential for an individual's proactivity. The results of the pilot study thus show that the Works Council member participants take a somewhat proactive approach to the implementation of workers' participation.

In this research, we detected a certain degree of interaction between autopoietic endowments and organizational energy. According to the value of the correlation coefficient, the correlation between Self-Awareness and Productive Energy is strong and statistically significant. The correlation between Independent Will and Productive Energy is moderate in terms of the value of the correlation coefficient and statistically significant in terms of the value of significance. However, the sample of the pilot study is too small to perform a regression analysis to verify the influence of the independent variable on the dependent concerning these correlations.

The results of the pilot study confirmed the interrelated influences of Autopoietic Endowments and Organizational Energy of Works Council members and appropriateness of the questionnaire for the continuation of the research study. In the main research, we will further examine the influence of the independent variable on the dependent and create a model of influences of Autopoietic Endowments of Works Council members on their Organizational Energy and relations with management. On this basis, we will provide suggestions for strengthening individual's endowments, which contribute to one's proactive approach towards workers' participation.

\section{References}

1. Brečko, D. (2012). Produktivno energijo so-ustvarjamo s sodelovanjem med vodstvom in zaposlenimi. ŠCID Kranj: Ekonomska demokracija, št. 1/2012, 3-7.

2. Brečko, D. (2017). O projektu. Pridobljeno na http://organizacijska-energija.si/index.php/oprojektu/\#1462892689309-76d01743-53c6

3. Budd, J. W., Gollan, P. J., \& Wilkinson, A. (2010). New approaches to employee voice and participation in organizations. Sage, Human Relations: 63(3), 303-310. doi: $10.1177 / 0018726709348938$

4. Bukovec, B. (2006). Management človeških virov in obvladovanje organizacijskih sprememb. Organizacija, 39(2), str. 117-123. Pridobljeno na https://www.dlib.si/stream/URN:NBN:SI:DOCN9PIQVEO/37cb015b-b660-4fd5-91c3-08c6e2d6bd16/PDF

5. Bulc, V. (2006). Ritmi poslovne evolucije. Ljubljana: Vibacom. Pridobljeno na http://vibacom.si/upload/RPE.pdf

6. Cho, E., \& Kim, S. (2014). Cronbach's Coefficient Alpha. Organizational Research Methods, 18(2), 207-230. doi:10.1177/1094428114555994

7. Covey, S. R. (1998). Sedem navad zelo uspešnih ljudi. Mladinska knjiga, Ljubljana.

8. Covey, S. R. (2004). The 8th habit: from effectiveness to greatness. New York: Free Press. 
9. Covey, S. R., Merrill, A. R., \& Merrill, R. R. (1997). Najprej najbolj pomembno. Založba Mladinska knjiga, Ljubljana.

10. Franca, V. (2009). Sodelovanje zaposlenih pri poslovnem odločanju: pravni in kadrovski vidiki s primeri iz sodne in podjetniške prakse. Ljubljana: Planet GV.

11. Ilievski, O. (2017). Libetova svobodna volja in fenomenologija odločanja, magistrsko delo. Univerza v Ljubljani, Fakulteta za družbene vede.

12. Lauc, A. (2000). Metodologija društvenih znanosti. Sveučilište J. J. Strossmayera u Osijeku, Pravni fakultet, Osijek.

13. Leary, M. R. (2000). Self-consciousness. Kazdin, A. E. (ur.), Encyclopedia of psychology, Vol. 7, 209-210). Washington, DC: American Psychological Association.

14. Leary, M. R. (2004). The curse of the self. Self-awareness, egotism and the quality of human life. New York: Oxford University Press.

15. Miles, M. B. \& Huberman A. M. (1994). Qualitative Data Analysis: An Expanded Sourcebook (2. izd.). Newbury Park, California: Sage Publications.

16. Možina, S. (2004). Zaupanje v organizaciji in participacija. ŠCID Kranj: Industrijska demokracija, št. $5 / 2004$.

17. Nunnally, J. C. (1978). Psychometric theory (2nd ed.). New York, NY: McGraw-Hill.

18. SQF (n.d.). Slovenian Qualifications Framework. Retrieved from https://www.nok.si/en

19. Silvia, P. J., \& O'Brian, M. E. (2004). Self-awareness and constructive functioning: Revisiting »the human dilemma.« Journal of Social and Clinical Psychology, 23, 475-489.

20. Van Teijlingen, E. R., \& Hundley, V. (2001). The importance of pilot studies. Social Research Update, (35). Pridobljeno na https://abdn.pure.elsevier.com/en/publications/the-importance-ofpilot-studies-2

21. Vaupotič, K., Mladič, M., Lužar Šajt, D., Gostiša, M., Slapnik, T., Medik B., Ćurčin, M., Šeperić, D., Šipek, L. \& Kantolić, J. (2015). S sodelovanjem do zaupanja in uspešnega poslovanja: priročnik za uvajanje participacije zaposlenih v poslovno prakso. Maribor: Fundacija za izboljšanje zaposlitvenih možnosti Prizma, ustanova: 9.

\section{Povzetek: \\ Medsebojni vpliv organizacijske energije in avtopoietičnih lastnosti članov sveta delavcev}

Raziskovalno vprašanje (RV): Raziskave kažejo, da organizacije potrebujejo za svoje delovanje energijo zaposlenih, ki izhaja iz njihovih procesov ustvarjanja, doseganja ciljev in medsebojnega sodelovanja na vseh ravneh. $\mathrm{V}$ raziskavi nas zanima, ali obstaja medsebojni vpliv organizacijske energije (energija malodušja, energija razjedanja, energija produktivnosti, energija udobja) in avtopoietičnih lastnosti (samozavedanje, vest, svobodna volja, ustvarjalna domišljija) zaposlenih. Kot ciljno skupino smo za izvedbo raziskave izbrali člane sveta delavcev $\mathrm{v}$ slovenskih organizacijah.

Namen: Namen raziskave je bil preučiti medsebojni vpliv organizacijske energije in avtopoietičnih lastnosti zaposlenih ob predpostavki, da se višja stopnja avtopoietičnih lastnosti odraža v višji vrednosti njihove kakovostne organizacijske energije. Hkrati je bil namen preveritev zanesljivosti vprašalnika.

Metoda: Za zbiranje informacij za potrebe raziskave smo uporabili metodo anketiranja. Kot merski inštrument smo uporabili vprašalnik, ki smo ga postavili na osnovi izhodišč dveh že oblikovanih vprašalnikov ter predhodno analizirane strokovne literature $\mathrm{z}$ našega interesnega področja. 
Rezultati: Izsledki raziskave potrjujejo medsebojni vpliv avtopoietičnih lastnosti in organizacijske energije članov sveta delavcev. Da bi pa lahko preverili vpliv neodvisne spremenljivke na odvisno, bi potrebovali večji vzorec. Rezultati tudi kažejo, da imajo anketirani člani svetov delavcev višjo vrednost kakovostnih kot nekakovostnih energij, kar nakazuje na njihovo konstruktivno uporabo osebnih potencialov.

Organizacija:

Obstoj medsebojnega vpliva avtopoietičnih lastnosti in organizacijske energije je pomembno spoznanje za organizacije, ki bo lahko prispevalo k razumevanju upravljanja energije zaposlenih.

Družba: Izvedena raziskava predstavlja prispevek k novim spoznanjem na področju uresničevanja delavskega soupravljanja v organizacijah v Sloveniji.

Originalnost: Tako v Sloveniji kot tudi v svetu obstaja veliko raziskav o obravnavani temi, nismo pa zasledili take, ki bi prepletala organizacijsko energijo in principe avtopoieze $\mathrm{v}$ kontekstu delavskega soupravljanja.

Omejitve/nadaljnje raziskovanje: Raziskava je potekala v obliki pilotne raziskave za namen preverjanja zanesljivosti vprašalnika. Pilotno anketiranje bi lahko razširili na večji vzorec, vendar smo se zaradi ločitve anketirancev med pilotno in glavno raziskavo odločili, da večji vzorec pridobimo v glavni raziskavi. Poskušali pa smo ublažiti omejitev tako, da smo iskali vzorec, ki je večji od 25, kar je sprejemljiva številka za izvedbo pilotne raziskave za namen testiranja vprašalnika.

Ključne besede: organizacija, delavsko soupravljanje, svet delavcev, člani sveta delavcev, avtopoietične lastnosti, organizacijska energija.

***

Mari Bozic holds a Bachelor of Science in Economics, a Bachelor of Science in Business Economics, and a Master of Science in Management. She has technical knowledge in the field of chemical activity, which she acquired during her SOK level 5 chemistry class. She has advanced her knowledge with experience that she has gained in managing employees and organizing work in both manufacturing and research and development. She is member of the Works Council and an internal auditor of the quality system. Her research interest is related to employees, their autopoietic endowments and organizational energy, and to relationships within the organization. At the Faculty of Organizational Studies, she is preparing a doctoral dissertation from the area of workers' participation in Slovenian organizations. She participates in professional and scientific conferences and publishes articles in scholarly publications.

Annmarie Gorenc Zoran is a Professor at the Faculty of Organisation Studies in Novo mesto as well as teaches distance learning courses abroad. Her research interest is an interdisciplinary approach to communication, as a channel in e-learning, framework for continuous improvement in terms of quality standards feedback, a tool in education and teaching, as an analytical framework to research, and as a contribution to management. She has published book chapters, numerous articles, and presented at international, national, and regional conferences.

$* * *$

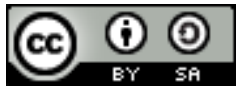

Creative Commons License

This work is licensed under a Creative Commons Attribution-ShareAlike 4.0 International License. 